\title{
The Effect Of IFRS Non-Audit Consulting Services On Cost Of Debt: Evidence From Korea
}

Seung Uk Choi, Korea University, South Korea

Woo Jae Lee, Chungnam National University, South Korea

\begin{abstract}
Korean listed firms have been required to disclose their financial statements based on the International Financial Reporting Standards (IFRS) since 2011. Using pre- and post-IFRS reporting periods, we investigate the relation between IFRS non-audit consulting services provided by incumbent auditor and the cost of debt of its client for firms in the Korean Stock Market. We find evidence that IFRS non-audit consulting services are related to the decrease in cost of debt only during the post-IFRS period. In particular, receiving non-audit consulting services is positively associated with a client's bond credit rating and negatively associated with interest rate. The result generally holds when we use alternative proxies of IFRS non-audit consulting services. Finally, our results are robust to potential endogeneity issues in selecting non-audit services.
\end{abstract}

Keywords: IFRS; IFRS Non-Audit Consulting Services; Cost Of Debt; Credit Rating; Interest Rate

\section{INTRODUCTION}

$Q$ nderstanding the benefits and costs of adopting International Financial Reporting Standards (IFRS) has become one of the major concerns to standard-setters and accounting professionals. However, empirical evidences of the effects of IFRS adoption on accounting quality are mixed. For instance, Barth et al. (2008) find that IFRS-adopting firms exhibit decreased income smoothing and increased timeliness of loss recognition. In contrast, Ahmed et al. (2013) find that accounting quality decreased after mandatory IFRS adoption. Although the former study uses voluntary adopters and the latter uses mandatory adopters, there exist different views of the effect of IFRS on accounting quality.

In our study, we investigate the effect of IFRS from a different point of view. In particular, we test whether auditor-provided IFRS consulting non-audit service (hereafter, ICS) is related to the decrease in cost of debt of the client firm. Given that creditors practically use numbers based on financial statements when they evaluate repayment capability of borrowers (Beatty et al. 2002; Francis et al. 2005), the cost of debt is a useful measure to examine the impact of new accounting standards on investors' perceptions of the credibility of financial statements.

We use firms listed on the Korean stock market that are required to report their annual financial statements under IFRS since 2011. Securities regulators of Korea allow firms to receive ICS from their incumbent auditors to prepare appropriate financial reporting systems based on IFRS. If ICS increases the credibility of financial statements and reduce the information asymmetry between firms and creditors as regulators intended, we expect that ICS from the auditor lowers client firm's cost of debt.

Our results suggest that ICS firms exhibit decrease in cost of debt only in the post-IFRS period. Specifically, receiving ICS is positively associated with a client's bond credit rating and negatively associated with interest rate. The results are generally consistent in the three different proxies of ICS and are robust to the existing endogeneity problem of selecting non-audit services from the incumbent auditor. 
Our study contributes to the literature in two ways. First, to the existing debate on the effect of IFRS adoption, we provide evidence that firms preparing mandatory IFRS adoption by receiving ICS from their auditors face favorable economic consequences. Second, our finding that the cost of debt decreases in firms with ICS suggests that certain non-audit services with strong guidelines by the regulator are beneficial to client firms.

The paper is organized as follows. Section II presents a background of IFRS adoption in Korea and introduces an ICS provision by auditors. Section III presents previous studies on the relation between non-audit services and cost of debt and introduces our hypothesis. Section IV presents data and methodology. Section V shows empirical results, and section VI concludes.

\section{IFRS ADOPTION IN KOREA AND IFRS RELATED NON-AUDIT CONSULTING SERVICES}

Korean capital markets have undergone fundamental changes arising from the mandatory adoption of IFRS in recent years. Korean listed firms expect some benefits as a consequence of the adoption of IFRS. For instance, adopting IFRS is motivated to improve both domestic and foreign investors' perception of the transparency of financial statements disclosed by domestic firms. ${ }^{1}$ Since the Korean economy is heavily dependent on exports and financial markets affected by foreign capital, international accounting standards are indeed required by Korean companies. Consequently, the Korean government announced a 'roadmap' for the adoption of IFRS in 2007. Under the roadmap, all Korean listed firms were required to prepare their annual financial statements under IFRS beginning in 2011.

To prepare for the mandatory IFRS adoption in 2011, most of the listed firms in Korea have purchased IFRS advisory services (ICSs) from their incumbent auditors as a non-audit service since 2007. Independent auditors in Korea are prohibited from providing consulting services related to establishing a financial information system to their audit clients following the Sarbanes-Oxley Act of 2002 (SOX). They are, however, allowed exceptionally to provide ICS to audit clients as long as they apply the Practical Guidelines (2008-1) of the Korea Financial Supervisory Service (K-FSS) with appropriate safeguards, which may reduce their self-review threat.

\section{LITERATURE REVIEW AND HYPOTHESIS DEVELOPMENT}

\subsection{The Effect of Non-Audit Services on Cost Of Debt}

There are conflicting predictions on the effect of non-audit services on the cost of debt. On the one hand, prior literature expects that non-audit services decrease accounting quality, thereby increasing cost of debt. DeAngelo (1981) argues that fees paid to auditors build up an economic bond between the clients and their incumbent auditors reducing perceived auditor independence. Consistent with this prediction, Frankel et al. (2002) find evidence that economic bonding impairs auditor independence. More directly, Brandon et al. (2004) find that the relative proportion of non-audit fees to total fees is negatively associated with the firm's bond rating.

On the other hand, there is evidence which implies that the auditor has no relations with client's cost of debt. For instance, Chung and Kallapur (2003) do not find a significant association between abnormal accruals and client importance measured as the ratio of total fees to total revenues or non-audit fees to total revenues. More closely related to the cost of debt, Ashbaugh et al. (2006) find that total fees paid to external auditors are not significantly associated with credit rating. ${ }^{2}$ In sum, these competing views suggest that the link between non-audit service provided by the auditor and cost of debt is not well established.

\footnotetext{
${ }^{1}$ This lack of reliability led to the Korean capital market suffering from the so-called 'Korea Discount' phenomenon, as global investors assess the Korean accounting system as lacking transparency.

${ }^{2}$ Although Ashbaugh et al. (2006) find no significant relations between total audit fees and credit ratings, they find other strong governances are positively associated with credit ratings. They find significant result when using blockholders, CEO power, takeover defense, accounting quality, and board characteristics for the governance proxies.
} 


\subsection{Hypothesis Development}

We predict that ICS decreases clients' cost of debt. There are two reasons to support this negative association. First, ICS increase the credibility of financial statements (Lee et al. 2013, 2014). For instance, Lee et al. (2013) find that firm's financial disclosure quality is higher when their auditor jointly provides audit and ICS. Similarly, Lee et al. (2014) find that the analysts' absolute forecast errors and forecast dispersions who follow the firms receiving ICS have decreased and the number of analysts following them has increased more than non-ICS firms. These results show that receiving ICS increases the credibility of financial statements, thereby reducing information asymmetry between firms and outside information users.

Second, due to the drastic changes in accounting regime from IFRS adoption in the Korean stock market, managers lack clear guidance regarding the new accounting standard. Therefore, preparing disclosure activities in advance by purchasing consulting services can improve investor perception of a firm's disclosure policy. Given that non-audit service fees paid to auditor reduce net income, managers are reluctant to purchase it from their incumbent auditor. The rating agencies may award relatively higher credit ratings to ICS purchased firms. Also the creditors may reward ICS purchasing firms by lowering interest rates. Consistent with this prediction, Attig et al. (2013) find that credit rating agencies tend to award relatively high ratings to firms with good social performance. They suggest that corporate social responsibility activities are costs for firms, but they also convey information to rating agencies when evaluating firms' value.

To summarize, if ICS increases the credibility of financial statements and when investors believe that the expected future cash flow predicted by these financial reports is reliable then the cost of debt is likely to be reduced in the post-IFRS period. Therefore, we test the following directional hypothesis.

Hypothesis: Receiving IFRS non-audit consulting service from the auditor is positively (negatively) associated with the client firm's credit ratings (interest rates) in the post-IFRS period.

\section{DATA AND METHODOLOGY}

\subsection{Sample and Data}

Our sample consists of Korean listed firms during the sampling period starting in 2008 and ending in 2012. Korean listed firms mandatorily adopted IFRS in 2011 so the years from 2008 to 2010 (2011 to 2012) are documented as pre-IFRS (post-IFRS) period.

The financial data used in our tests are extracted from the Total Solution (TS) 2000 database, which is provided by the Korea Listed Company Association. Non-audit services and other auditor characteristics were manually collected from K-FSS internet based disclosure system. ${ }^{3}$ We only include firms with fiscal years ending in

December, ${ }^{4}$ and firms not operate in the financial industry. All continuous variables are winsorized at 1 percent and 99 percent.

Table 1 presents the sample distribution. Panel A of Table 1 shows yearly distribution of the sample. The total sample, which consists of 1,139 firm-years, includes 124 ICS-firms. Among ICS-firms, about $83 \%$ of the firms (103 firms out of 124 total firms) received ICS in the pre-IFRS period. This means that most of ICS-firms prepared new accounting standards before mandatory adoption of IFRS. Panel B presents the sample distribution by industry. We use the two-digit Korean Standard Industrial Classification (KSIC) code. 55 percent (56 percent) of total (ICS) firm-years are in the manufacturing industry (KSIC 10-33).

\footnotetext{
${ }^{3}$ K-FSS provides mandatory disclosed information of firms (http://dart.fss.or.kr/) similar to the Edgar filings in US.

${ }^{4}$ The fiscal year end of the most of Korean listed manufacturing firms is in December, whereas financial firms' fiscal year ends in March. 


\subsection{Research Design}

\subsubsection{Measuring IFRS Non-Audit Consulting Service}

We measure ICS, which is our main independent variable with three different proxies (Lee et al. 2014). The first proxy is CONSULTING that equals one if a client received consulting services from its incumbent auditor and zero otherwise. The second measure is FREQUENCY which indicates the cumulative number of consulting services that a client firm has received. Lastly, a third measure is FEE, which is calculated as the natural logarithm of the cumulative fees paid to auditors providing ICS.

Table 1. Sample distribution

Panel A. Distribution by year

\begin{tabular}{ccc}
\hline Year & Total sample & ICS sample \\
\hline 2008 & 203 & 21 \\
2009 & 204 & 39 \\
2010 & 227 & 43 \\
2011 & 241 & 14 \\
2012 & 264 & 7 \\
\hline Total & 1,139 & 124 \\
\hline
\end{tabular}

Panel B. Distribution by industry

\begin{tabular}{llcc}
\hline KSIC Code & \multicolumn{1}{c}{ Industry Name } & Total sample & ICS sample \\
\hline $1 \sim 3$ & Agriculture, forestry and fishing & 4 & 0 \\
$10 \sim 33$ & Manufacturing & 628 & 69 \\
$35 \sim 36$ & Electricity, gas, steam and water supply & 28 & 2 \\
$37 \sim 39$ & Sewage, waste management, materials recovery and remediation activities & 5 & 0 \\
$41 \sim 42$ & Construction & 142 & 14 \\
$45 \sim 47$ & Wholesale and retail trade & 98 & 11 \\
$49 \sim 52$ & Transportation & 53 & 2 \\
$55 \sim 56$ & Accommodation and food service activities & 1 & 0 \\
$58 \sim 63$ & Information and communications & 73 & 6 \\
$70 \sim 73$ & Professional, scientific and technical activities & 105 & 20 \\
85 & Education & 2 & 0 \\
Total & & 1,139 & 124 \\
\hline
\end{tabular}

\subsubsection{Measuring Cost of Debt}

We measure firms' cost of debt by using two different proxies. First, following related studies, we use credit ratings (Bhojraj and Sengupta, 2003; Ashbaugh-Skaife et al., 2006; Attig et al., 2013 among others). Firms that issue corporate bonds are obliged to receive credit ratings from the licensed rating agencies. In Korea, there are three major credit rating agencies which provide bond issuers' ratings. ${ }^{5}$ We extract credit ratings data from the FN Data Guide database. To evaluate firms more conservatively, we use the lowest ratings among the three rating agencies. ${ }^{6}$ We assign a value of 19 if the firm has the highest ratings of AAA and 1 for the lowest rating of C, following prior studies. ${ }^{7}$

Our second measure of cost of debt is interest rate. Following Pittman and Fortin (2004) and Francis et al. (2005) we calculated interest rate as interest expense divided by average of short- and long-term debt during the year. We expect increase in credit ratings and decrease in interest rates are associated with a decrease in the cost of debt.

\footnotetext{
${ }^{5}$ Those are Korea Investors Service (KIS), National Information \& Credit Evaluation Inc. (NICE), and Korea Ratings (KR).

${ }^{6}$ The result is qualitatively similar when we use each credit ratings provided by different three rating agencies.

${ }^{7}$ Specifically, a value of 19 is assigned if the firm's rating is AAA, 18 if AA+, 17 if AA, 16 if AA-, 15 if A+, 14 if A, 13 if A-, 12 if BBB+, 11 if BBB, 10 if BBB-, 9 if BB+, 8 if BB, 7 if BB-, 6 if B+, 5 if B, 4 if B-, 3 if CCC, 2 if CC, and 1 if C.
} 


\subsubsection{Difference-in-Differences Approach}

We employ the pre-IFRS period and the firms that do not purchase ICS as a benchmark sample. In our difference-in-differences design, we expect significant and negative association between receiving ICS and cost of debt in the post-IFRS period compared to the benchmark sample. The difference-in-differences approach is widely used in the literature when the effect of the change in the economic environment and contemporaneous change in time effect over years of the sample period co-exist (Daske et al., 2008; Ahmed et al. 2013). We estimate the following regression model:

$$
\begin{aligned}
& \operatorname{COD}_{i, t}=\beta_{0}+\beta_{1} * \operatorname{ICS}_{i, t}+\beta_{2} * \operatorname{IFRS}_{t}+\beta_{3} * \boldsymbol{I C S}_{i, t} * \boldsymbol{I F R S}_{t}+\beta_{4} * \operatorname{SIZE}_{i, t}+\beta_{5}{ }^{*} L E V_{i, t}+\beta_{6} * R O A_{i, t} \\
& +\beta_{7} * C_{i, t}+\beta_{8}{ }^{*} E_{\text {XPORT }}+\beta_{i, t}+\beta_{9}{ }^{*}{ }^{*} W_{i, t}+\beta_{10} * \operatorname{LOSS}_{i, t}+\beta_{11} * B E T A_{i, t}+\beta_{12} * B I G_{i, t} \\
& +\beta_{13} * O P N_{i, t}+\beta_{14} * L_{A R G E_{i, t}}+\beta_{15} * \text { FOREIGN } N_{i, t}+\text { Industry FE }+\varepsilon_{i, t}
\end{aligned}
$$

The dependent variable $C O D$ is a firm's cost of debt defined as credit ratings or interest rates. ICS is measured by following three different proxies: (1) CONSULTING, (2) FREQUENCY, and (3) FEE. IFRS equals one if it is post-IFRS period, and zero otherwise. Since Korea adopted IFRS mandatorily in 2011, the IFRS variable equals zero from 2008 to 2010, and equals one in 2011 and 2012 in our sample. If firms that have received ICS from auditors are associated with cost of debt in the post IFSR period, then we expect significant $\beta_{3}$. In particular, when the dependent variable is credit ratings (interest rate) then significant and positive (negative) $\beta_{3}$ supports our hypothesis.

Following prior literature, we include variables that are known to have an effect on the cost of debt. First, firm size $(S I Z E)$ is included because large firms are expected to have lower credit risk. Financial statement based default risk and performance variables are also controlled ( $L E V, R O A$, and $C F O$ following Ashbaugh et al. 2006 and Dhaliwal et al. 2008). Sales export to total sales (EXPORT) is included to control firm complexity, and sales growth $(G R W)$ controls growth opportunities. A firm reporting a net loss $(L O S S)$ is controlled because it is directly related to default risk. Stock return beta (BETA) is included to capture systematic risk of the firm. We also include the auditor characteristic such as auditor size $(B I G)$ and audit opinion $(O P N)$. Ownership of largest shareholder and its related parties (LARGE) as well as foreign ownership (FOREIGN) are included to control governance effects. Finally, we include industry fixed dummies to control the individual industry effect on the relation between the independent and dependent variables. ${ }^{8}$ Statistical significance reported in tables is based on the firm-level clustering.

\section{RESULTS}

\subsection{Descriptive Statistics}

Descriptive statistics regarding the sample are provided in Panel A of Table 2. The mean value of CONSULTING is 0.11 showing that about $11 \%$ of our sample firms purchased ICS from their incumbent auditors at least once. The mean value of FREQUENCY is 0.45 and it is higher than mean value of CONSULTING because it reveals a cumulative frequency of ICS. Mean value of FEE is 3.88. RATING indicates credit ratings provided by rating agencies, and its mean value is 12.32 (between $\mathrm{BBB}+$ and $\mathrm{BBB}$ ). The mean and median values of interest rate $(I R)$ are both $3 \%$. Panel B of Table 2 presents mean and median difference between ICS and non-ICS firms. Confirming our hypothesis, both mean and median RATING of ICS firms are higher than that of non-ICS firms (tvalue 2.80 and z-value 2.76). Also, $I R$ is significantly lower for ICS firms than non-ICS firm (t-value -1.83 and zvalue -1.96). The results of this univariate test generally support our hypothesis. Considering other variables, it is interpreted that ICS firms are larger, have higher performance and sales from foreign countries, report less losses, and foreign investors own more than in non-ICS firms.

The untabualted pearson correlation results show that the correlation among ICS variables are positively significant $(0.48$ between CONSULTING and FREQUENCY, 0.50 between CONSULTING and FEE, and 0.89 between FREQUENCY and FEE). As expected, ICS variables are positively (negatively) associated with RATING

\footnotetext{
${ }^{8}$ Due to IFRS dummy variable, we do not include year fixed effect in our regression model to avoid multicollinearity problem. 
$(I R)$. Other control variables show consistent correlation with ICS variables presented in the univariate test from Table 2.

Table 2. Descriptive statistics

\begin{tabular}{|c|c|c|c|c|c|c|c|}
\hline Variables & Mean & STD & P1 & P25 & Median & P75 & P99 \\
\hline \multicolumn{8}{|l|}{ ICS variables } \\
\hline CONSULTING & 0.11 & 0.31 & 0.00 & 0.00 & 0.00 & 0.00 & 1.00 \\
\hline FREQUENCY & 0.45 & 0.74 & 0.00 & 0.00 & 0.00 & 1.00 & 3.00 \\
\hline FEE & 3.88 & 5.61 & 0.00 & 0.00 & 0.00 & 11.16 & 13.62 \\
\hline \multicolumn{8}{|c|}{ Cost of debt variables } \\
\hline RATING & 12.32 & 4.16 & 3.00 & 10.00 & 13.00 & 16.00 & 19.00 \\
\hline$I R$ & 0.03 & 0.02 & 0.00 & 0.02 & 0.03 & 0.04 & 0.10 \\
\hline \multicolumn{8}{|c|}{ Control variables } \\
\hline SIZE & 26.81 & 2.00 & 22.31 & 25.28 & 26.72 & 28.44 & 30.95 \\
\hline$L E V$ & 0.54 & 0.18 & 0.10 & 0.42 & 0.56 & 0.66 & 0.96 \\
\hline$R O A$ & 0.01 & 0.12 & -0.53 & -0.01 & 0.02 & 0.06 & 0.24 \\
\hline CFO & 0.04 & 0.10 & -0.27 & -0.01 & 0.04 & 0.09 & 0.32 \\
\hline EXPORT & 0.01 & 0.10 & 0.00 & 0.00 & 0.00 & 0.00 & 0.62 \\
\hline$G R W$ & 0.12 & 0.40 & -0.87 & -0.03 & 0.08 & 0.20 & 2.26 \\
\hline LOSS & 0.25 & 0.43 & 0.00 & 0.00 & 0.00 & 0.00 & 1.00 \\
\hline BETA & 0.86 & 0.40 & 0.04 & 0.56 & 0.86 & 1.14 & 1.77 \\
\hline$B I G$ & 0.82 & 0.39 & 0.00 & 1.00 & 1.00 & 1.00 & 1.00 \\
\hline$O P N$ & 0.01 & 0.07 & 0.00 & 0.00 & 0.00 & 0.00 & 0.00 \\
\hline$L A R G E$ & 0.39 & 0.17 & 0.06 & 0.27 & 0.38 & 0.50 & 0.84 \\
\hline FOREIGN & 0.12 & 0.14 & 0.00 & 0.01 & 0.07 & 0.18 & 0.60 \\
\hline
\end{tabular}

Panel B. Mean and median differences

\begin{tabular}{l|rcc|rcc}
\hline & \multicolumn{3}{|c|}{ Mean differences } & \multicolumn{3}{c}{ Median differences } \\
\hline \multicolumn{1}{c|}{ Variables } & ICS & Non- ICS & t-value & \multicolumn{1}{c}{ ICS } & Non- ICS & z-value \\
\hline RATING & 13.23 & 12.21 & $2.80^{* * *}$ & 14.00 & 13.00 & $2.76^{* * *}$ \\
IR & 0.03 & 0.03 & $-1.83^{* * *}$ & 0.03 & 0.03 & $-1.96^{* *}$ \\
SIZE & 27.45 & 26.74 & $3.99^{* * *}$ & 27.52 & 26.64 & $3.88^{* * *}$ \\
LEV & 0.52 & 0.54 & -1.48 & 0.55 & 0.56 & -1.27 \\
ROA & 0.04 & 0.00 & $4.22^{* * *}$ & 0.03 & 0.02 & $2.90^{* * *}$ \\
CFO & 0.04 & 0.04 & 0.74 & 0.04 & 0.04 & 0.55 \\
EXPORT & 0.06 & 0.01 & $2.76^{* * *}$ & 0.00 & 0.00 & $4.90^{* * *}$ \\
GRW & 0.15 & 0.12 & 0.80 & 0.11 & 0.08 & $1.89^{*}$ \\
LOSS & 0.14 & 0.26 & $-3.60^{* * *}$ & 0.00 & 0.00 & $-2.98^{* * *}$ \\
BETA & 0.89 & 0.86 & 0.70 & 0.90 & 0.85 & 0.76 \\
BIG & 0.87 & 0.81 & $1.84^{*}$ & 1.00 & 1.00 & 1.64 \\
OPN & 0.00 & 0.01 & $-2.46^{* *}$ & 0.00 & 0.00 & -0.86 \\
LARGE & 0.39 & 0.39 & -0.43 & 0.36 & 0.38 & -0.68 \\
FOREIGN & 0.15 & 0.12 & $2.58^{* *}$ & 0.10 & 0.06 & $2.83^{* * *}$ \\
\hline
\end{tabular}

See Section 4 for variable definitions. *, **,*** denotes significance at the $0.10,0.05$ and 0.01 level, respectively.

\subsection{IFRS Non-Audit Consulting Service and Credit Ratings}

Table 3 reports the results of examining ICS effects on credit ratings. Given the discrete nature of our dependent variable $(R A T I N G)$, we use an ordered logit model. We present the results separately for each ICS variable (CONSULTING, FREQUENCY, and FEE). The results show that the coefficients of ICS*IFRS are positively significant in all three columns (p-values are $0.011,0.020$, and 0.058 , respectively). Consistent with our hypothesis, this result suggests that rating agencies incrementally award firms receiving ICS from their auditors. In contrast, the coefficients of ICS are negatively significant ( $\mathrm{p}$-values are $0.014,0.074$, and 0.040 , respectively) meaning that firms that purchased ICS before IFRS adoption faced reduction in credit ratings. ${ }^{9}$ The coefficients of

\footnotetext{
${ }^{9}$ It is not clear why credit ratings of firms receiving ICS before IFRS adoption are lower than that of non-ICS firms. One possible explanation is that the costs paid to the auditor for ICS, which might decrease net income is a non-trivial input in credit agencies' assessment of firms'
} 
IFRS are all positively significant (p-values are $0.001,0.004$, and 0.005 , respectively). It can be interpreted that the effect of IFRS adoption has improved credit ratings of Korean listed firms. Overall, we observe an incremental increase in credit ratings for ICS firms relative to benchmark firms. The remaining control variables are generally consistent with prior research. SIZE, ROA, EXPORT, GRW, BIG, LARGE, and FOREIGN are positively associated with credit ratings. However, LEV, LOSS, and BETA are negatively associated with credit ratings. Pseudo $\mathrm{R}^{2}$ is about $82 \%$, and it implies that our selected variables explain the dependent variable well.

Table 3. Ordered logit analysis: the effect of ICS on credit ratings

\begin{tabular}{|c|c|c|c|c|c|c|}
\hline \multicolumn{7}{|c|}{ Dependent variable $=$ Credit ratings } \\
\hline & \multicolumn{2}{|c|}{$I C S=$ Consulting } & \multicolumn{2}{|c|}{$I C S=$ Frequency } & \multicolumn{2}{|c|}{$I C S=$ Fee } \\
\hline & Coeff & p-value & Coeff & p-value & Coeff & p-value \\
\hline ICS & $-0.525 * *$ & $(0.014)$ & $-0.277 *$ & $(0.074)$ & $-0.038 * *$ & $(0.040)$ \\
\hline IFRS & $0.365 * * *$ & $(0.001)$ & $0.358 * * *$ & $(0.004)$ & $0.368 * * *$ & $(0.005)$ \\
\hline$I C S * I F R S$ & $0.949 * *$ & (0.011) & $0.295 * *$ & $(0.020)$ & $0.033 *$ & $(0.058)$ \\
\hline SIZE & $1.219 * * *$ & $(<.001)$ & $1.229 * * *$ & $(<.001)$ & $1.229 * * *$ & $(<.001)$ \\
\hline$L E V$ & $-1.418 * *$ & $(0.015)$ & $-1.387 * *$ & $(0.017)$ & $-1.366 * *$ & $(0.019)$ \\
\hline$R O A$ & $3.588 * * *$ & $(<.001)$ & $3.584 * * *$ & $(<.001)$ & $3.585 * * *$ & $(<.001)$ \\
\hline CFO & -0.464 & $(0.586)$ & -0.442 & $(0.603)$ & -0.470 & $(0.581)$ \\
\hline EXPORT & $1.153 *$ & $(0.091)$ & $1.225 *$ & $(0.077)$ & $1.194 *$ & $(0.081)$ \\
\hline$G R W$ & $0.007 * * *$ & $(<.001)$ & $0.007 * * *$ & $(<.001)$ & $0.007 * * *$ & $(<.001)$ \\
\hline LOSS & $-1.580 * * *$ & $(<.001)$ & $-1.569 * * *$ & $(<.001)$ & $-1.574 * * *$ & $(<.001)$ \\
\hline BETA & $-0.939 * * *$ & $(<.001)$ & $-0.973 * * *$ & $(<.001)$ & $-0.973 * * *$ & $(<.001)$ \\
\hline$B I G$ & $0.941 * * *$ & $(<.001)$ & $0.935 * * *$ & $(<.001)$ & $0.943 * * *$ & $(<.001)$ \\
\hline$O P N$ & -0.980 & $(0.548)$ & -0.977 & $(0.548)$ & -0.993 & $(0.541)$ \\
\hline$L A R G E$ & $1.942 * * *$ & $(0.001)$ & $1.917 * * *$ & $(0.001)$ & $1.902 * * *$ & $(0.001)$ \\
\hline FOREIGN & $5.278 * * *$ & $(<.001)$ & $5.309 * * *$ & $(<.001)$ & $5.321 * * *$ & $(<.001)$ \\
\hline Industry FE & & \multicolumn{2}{|c|}{ Included } & \multicolumn{2}{|c|}{ Included } \\
\hline Likelihood Ratio & \multicolumn{2}{|c|}{$1966.65^{* * *}$} & \multicolumn{2}{|c|}{$1964.17^{* * *}$} & \multicolumn{2}{|c|}{$1965.83^{* * *}$} \\
\hline Wald $X^{2}$ & \multicolumn{2}{|c|}{$560.35^{* * *}$} & \multicolumn{2}{|c|}{$536.87^{* * *}$} & \multicolumn{2}{|c|}{$537.31^{* * *}$} \\
\hline Pseudo $\mathrm{R}^{2}$ & \multicolumn{2}{|c|}{0.8221} & & \multicolumn{2}{|c|}{0.8220} \\
\hline $\mathrm{N}$ & \multicolumn{2}{|c|}{1,139} & \multicolumn{2}{|c|}{1,139} & \multicolumn{2}{|c|}{1,139} \\
\hline
\end{tabular}

See Section 4 for variable definitions. ${ }^{*}, * *, * * *$ denotes significance at the $0.10,0.05$ and 0.01 level, respectively. Standard errors are corrected for firm-level clustering.

\subsection{IFRS Non-Audit Consulting Service and Interest Rates}

Table 4 provides the results of OLS regressions that analyze the relation between ICS and interest rates. The coefficients of ICS*IFRS are negative and significant when ICS is measured by the number of receiving ICS (FREQUENCY) and the cumulative costs paid to auditor (FEE) (p-values are 0.030 and 0.042 , respectively). The coefficient of ICS*IFRS in the first column is negative, but insignificant (p-value is 0.525 ). The results are somewhat weaker in Table 4 than in Table 3, but it generally supports our hypothesis that creditors award firms receiving ICS from their auditors by lowering interest rates. The coefficients of IFRS are also negatively significant in all three regressions ( $\mathrm{p}$-values are $<0.001,0.015$, and 0.026 , respectively). The control variables are consistent with our prediction. In sum, the results in Table 4 suggest that the IFRS adoption decrease interest rate of listed firms in Korean stock market and there is a significant incremental effect of ICS on interest rate beyond IFRS adoption. ICS-firms that issue corporate bonds receive favorable interest rates from the creditors.

performance. The other possibility is that the credit ratings of firms who purchase ICS are endogenously lower than that of non-ICS firms. We test this endogeneity issue in section 5.4. 
Table 4. OLS analysis: the effect of ICS on interest rates

\begin{tabular}{|c|c|c|c|c|c|c|}
\hline \multicolumn{7}{|c|}{ Dependent variable $=$ Interest rates } \\
\hline & \multicolumn{2}{|c|}{$I C S=$ Consulting } & \multicolumn{2}{|c|}{$I C S=$ Frequency } & \multicolumn{2}{|c|}{$I C S=$ Fee } \\
\hline & Coeff & p-value & Coeff & p-value & Coeff & p-value \\
\hline INTERCEPT & $0.071 * * *$ & $(<.001)$ & $0.072 * * *$ & $(<.001)$ & $0.073 * * *$ & $(<.001)$ \\
\hline ICS & 0.000 & $(0.991)$ & 0.001 & $(0.437)$ & 0.000 & $(0.409)$ \\
\hline IFRS & $-0.003 * * *$ & $(<.001)$ & $-0.002 * *$ & $(0.015)$ & $-0.002 * *$ & $(0.026)$ \\
\hline$I C S * I F R S$ & -0.002 & $(0.525)$ & $-0.002 * *$ & (0.030) & $-0.000 * *$ & $(0.042)$ \\
\hline SIZE & $-0.002 * * *$ & $(0.001)$ & $-0.002 * * *$ & $(0.001)$ & $-0.002 * * *$ & $(0.001)$ \\
\hline$L E V$ & $0.019 * * *$ & $(<.001)$ & $0.019 * * *$ & $(<.001)$ & $0.019 * * *$ & $(<.001)$ \\
\hline$R O A$ & $-0.041 * * *$ & $(<.001)$ & $-0.041 * * *$ & $(<.001)$ & $-0.041 * * *$ & $(<.001)$ \\
\hline $\mathrm{CFO}$ & -0.011 & $(0.136)$ & -0.011 & $(0.127)$ & -0.011 & $(0.132)$ \\
\hline EXPORT & $-0.009 *$ & $(0.053)$ & $-0.010 * *$ & $(0.031)$ & $-0.010 * *$ & $(0.032)$ \\
\hline$G R W$ & 0.000 & $(0.575)$ & 0.000 & $(0.555)$ & 0.000 & $(0.553)$ \\
\hline LOSS & $0.006 * * *$ & $(<.001)$ & $0.006 * * *$ & $(<.001)$ & $0.006 * * *$ & $(<.001)$ \\
\hline BETA & 0.000 & $(0.990)$ & 0.000 & $(0.931)$ & 0.000 & $(0.932)$ \\
\hline$B I G$ & 0.000 & $(0.977)$ & 0.000 & $(0.961)$ & 0.000 & $(0.957)$ \\
\hline$O P N$ & 0.035 & $(<.001)$ & $0.036 * * *$ & $(<.001)$ & $0.036 * * *$ & $(<.001)$ \\
\hline$L A R G E$ & $-0.008 *$ & $(0.063)$ & $-0.008 *$ & $(0.059)$ & $-0.008 *$ & $(0.059)$ \\
\hline FOREIGN & $-0.015 * *$ & $(0.026)$ & $-0.014 * *$ & $(0.029)$ & $-0.014 * *$ & $(0.031)$ \\
\hline $\begin{array}{l}\text { Industry FE } \\
\text { Adj. } \mathrm{R}^{2} \\
\mathrm{~N}\end{array}$ & Included & & & & & \\
\hline
\end{tabular}

See Section 4 for variable definitions. ${ }^{*}, * *, * * *$ denotes significance at the $0.10,0.05$ and 0.01 level, respectively. Standard errors are corrected for firm-level clustering.

\subsection{Controlling Endogeneity}

The preceding results show that ICS is exogenously determined. However, if client characteristics affect selecting decisions in non-audit services then our results suffer from a potential omitted variable problem. Following prior research, we use a two-stage regression procedure to mitigate endogeneity issues (Heckman, 1979). In the first stage, we regress the CONSULTING variable on the determinant variables that affect clients' selecting decisions of non-audit services. ${ }^{10}$ We then redo our analysis by including IMR (Inverse Mill's Ratio) variables in each regression model. The untabulated results are consistent with our hypothesis that suggest ICS is positively associated with credit ratings and negatively related to interest rates in post-IFRS period.

\section{CONCLUSION}

Motivated by worldwide debate on the effect of IFRS adoption on the economic consequences of adopters, this study investigates the effect of ICS on the cost of debt of adopting-firms. We find that ICS provided from an external auditor is related to a decrease in cost of debt in the post IFRS period of Korean listed firms. In particular, receiving ICS is positively associated with a client's bond credit ratings and negatively associated with interest rates. This result suggests that creditors reward firms that prepare IFRS adoption in advance by purchasing ICS from their incumbent auditors. The result generally holds when we use the indicator variable of receiving ICS, cumulative ICS fees, and cumulative frequency of receiving ICS. Finally, our results are robust even after controlling endogeneity problem arising from the client firm's decision to purchase non-audit services from their incumbent auditor.

\section{AUTHOR INFORMATION}

Seung Uk Choi (first author) is Ph. D. candidate at the Korea University Business School.

Woo Jae Lee (corresponding author) is visiting professor of School of Business at the Chungnam National University. E-mail: wjlie@korea.ac.kr

\footnotetext{
${ }^{10}$ In the first stage, we regress CONSULTING on the determinant variables that affect clients' selecting decisions of non-audit services. We include firm size, total accruals, sales from foreign countries, audit fee, non-audit fee, and Big N.
} 


\section{REFERENCES}

Ahmed, A. S., M. Neel, and D. Wang. 2013. Does mandatory adoption of IFRS improve accounting quality? Preliminary evidence. Contemporary Accounting Research 30 (1): 388-423.

Ashbaugh-Skaife, H., D. W. Collins, and R. LaFond. 2006. The effects of corporate governance on firms' credit ratings. Journal of Accounting and Economics 42 (1): 203-243.

Attig, N., S. E. Ghoul, O. Guedhami, and J. Suh. 2013. Corporate social responsibility and credit ratings. Journal of Business Ethics 117 (4): 679-694.

Barth, M. E., W. R. Landsman, and M. H. Lang, 2008. International accounting standards and accounting quality. Journal of Accounting Research 46 (3): 467-498.

Beatty, A., K. Ramesh, and J. Weber. 2002. The importance of accounting changes in debt contracts: the cost of flexibility in covenant calculations. Journal of Accounting and Economics 33 (2): 205-227.

Bhojraj, S., and P. Sengupta. 2003. Effect of corporate governance on bond ratings and yields: The role of institutional investors and outside directors. Journal of Business 76 (3): 455-475.

Brandon, D. M., A. D. Crabtree, and J. J. Maher. 2004. Nonaudit fees, auditor independence, and bond ratings. Auditing: A Journal of Practice \& Theory 23 (2): 89-103.

Chung, H., and S. Kallapur. 2003. Client importance, nonaudit services, and abnormal accruals. The Accounting Review 78 (4): 931-955.

Daske, H., L. Hail, C. Leuz, and R. Verdi. 2008. Mandatory IFRS reporting around the world: Early evidence on the economic consequences. Journal of Accounting Research 46 (5): 1085-1142.

DeAngelo, L. E. 1981. Auditor size and audit quality. Journal of Accounting and Economics 3 (3): 183-199.

Dhaliwal, D. S., C. A. Gleason, S. Heitzman, and K. D. Melendrez. 2008. Auditor fees and cost of debt. Journal of Accounting, Auditing \& Finance 23 (1): 1-22.

Francis, J. R., I. K. Khurana, and R. Pereira. 2005. Disclosure incentives and effects on cost of capital around the world. The Accounting Review 80 (4): 1125-1162.

Francis, J., R. LaFond, P. Olsson, and K. Schipper. 2005. The market pricing of accruals quality. Journal of Accounting and Economics 39 (2): 295-327.

Frankel, R. M., M. F. Johnson, and K. K. Nelson. 2002. The relation between auditor's fees for non-audit services and earnings management. The Accounting Review 77 (Supplement): 71-105.

Heckman, J. J. 1979. Sample selection bias as a specification error. Econometrica 47: 153-161.

Korean Financial Supervisory Service. 2008. Practical Guideline (2008-1). Seoul: Republic of Korea Government Printing Office.

Lee, W. J., K. W. Oh, and S. W. Jeong. 2013. The Effect of Audit Quality on Financial Disclosure Quality: Focused on the Provision of K-IFRS Advisory Service by Incumbent Auditors. Korean Accounting Journal 22 (6): 69-107.

Lee, W. J., S. W. Jeong, and S. U. Choi. 2014. The effects of provision of incumbent auditors' IFRS advisory service on the analysts' forecast accuracy and demand: focused on K-IFRS consolidated financial statements. Korean Accounting Review 39 (3): 249-290.

Pittman, J. A., and S. Fortin. 2004. Auditor choice and the cost of debt capital for newly public firms. Journal of Accounting and Economics 37 (1): 113-136. 


\section{NOTES}

